Portland State University

PDXScholar

8-1-1992

\title{
Regional City and Network City: Portland and Seattle in the Twentieth Century
}

Carl Abbott

Portland State University, d3ca@pdx.edu

Follow this and additional works at: https://pdxscholar.library.pdx.edu/usp_fac

Part of the Urban Studies and Planning Commons

Let us know how access to this document benefits you.

\section{Citation Details}

Abbott, C. Regional City and Network City: Portland and Seattle in the Twentieth Century. The Western Historical Quarterly , Vol. 23, No. 3 (Aug., 1992), pp. 293-322.

This Article is brought to you for free and open access. It has been accepted for inclusion in Urban Studies and Planning Faculty Publications and Presentations by an authorized administrator of PDXScholar. Please contact us if we can make this document more accessible: pdxscholar@pdx.edu. 


\title{
Regional City and Network City: Portland and Seattle in the Twentieth Century
}

\author{
CARL AbBotT
}

\section{$\mathrm{E}$} conomic and social interactions in the United States have undergone a massive expansion of scale since the mid-nineteenth century. The change is apparent in the size and scope of business enterprise, government operations, and organized social movements. As Kenneth Boulding pointed out nearly forty years ago, the result has been an "organizational revolution." The relatively isolated and self-contained "island communities" described by Robert Wiebe have been encompassed by a web of national institutions, obligations, and interactions. One result has been the intensification of extra local ties and connections at the expense of local relationships. ${ }^{1}$

Scholars interested in the elaboration of organization and the expansion of scale have given particular attention to the industrial transformation of the United States between 1870 and 1920. Understanding modernization as the interactive development of mass production, industrial cities, and bureaucracy, these scholars help us understand both the rise of the central state and the cultural process of nation-building. In detail,

Carl Abbott is professor of urban studies and planning at Portland State University.

${ }^{1}$ In Kenneth Boulding, The Organizational Revolution (New York, 1952), the author explored the social and cultural consequences of the expansion of institutional scale since the early twentieth century. Robert Wiebe made the increasing scale and integration of American institutions the central theme for interpreting the transition from nineteenth to twentieth century in Robert H. Wiebe, The Search for Order, 1877-1920 (New York, 1967) and restated the same interpretation for a longer time span in Robert H. Wiebe, The Segmented Society (New York, 1975). Organizational change as a synthesizing principle for United States history has been proposed in Louis Galambos, "The Emerging Organizational Synthesis in Modern American History," Business History Review 44 (Autumn 1970): 279-90; in Louis Galambos, "Technology, Political Economy, and Professionalization: Central Themes of the Organizational Synthesis," Business History Review 57 (Winter 1983): 471-93; and Louis Galambos, America at Middle Age: A New History of the United States in the Twentieth Century (New York, 1982). The "organizational synthesis" has been examined by Robert F. Berkhofer, Jr., "The Organizational Interpretation of American History: A New Synthesis," Prospects 4 (1979): 611 29; and Robert D. Cuff, "American Historians and the 'Organizational Factor," Canadian Review of American Studies 4 (Spring 1973): 19-31. This approach can be viewed as a refinement or specification of modernization theory, which was developed by Emile Durkheim, Georg Simmel, Max Weber, and others to explain the broad outlines of societal change. 
many of their studies deal with the emergence of national organizations, institutions, and fields of action: corporations, universities, federal agencies, labor unions, professions, industrial sectors, and policy arenas. ${ }^{2}$ For the twentieth century, mainstream social science has tended to assume the continuing expansion of social scale and to explore the erosion of local and regional affiliations. ${ }^{3}$

The expanding scale of economic activity, in contrast, raises the question of differentiation as well as homogenization. In the twentieth century, further transitions of economic organization have depended upon the ability of corporations to use new technologies of distribution and control to manage multilocational enterprises. The results can be viewed as a redefinition of specialization within increasingly complex national and global systems. ${ }^{4}$ This redefinition opens the basic historical question of differential impacts on individual communities. Local heritage, local character, and conscious local choices have all mediated the effects of economic scale-change.

Specifically, American cities have responded differently to opportunities created by the rise of an interconnected world economy. This essay examines the range of such responses by analyzing the experiences of twentieth-century Portland and Seattle. Separated by 175 miles of highway or rail line, the cities have similar early histories, analogous economic bases, and parallel demographic profiles, and have long competed against each other for regional dominance. Nevertheless, they have diverged in their

${ }^{2}$ Alfred D. Chandler, Jr., The Visible Hand: The Managerial Revolution in American Business (New York, 1977); Laurence R. Veysey, The Emergence of the American University (Chicago, 1965); Stephen Skowronek, Building a New American State: The Expansion of National Administrative Capacities, 1877-1920 (New York, 1982); Thomas L. Haskell, The Emergence of Professional Social Science: The American Social Science Association and the Nineteenth-Century Crisis of Authority (Urbana, IL, 1977); Burton J. Bledstein, The Culture of Professionalism: The Middle Class and the Development of Higher Education in America (New York, 1976); Olivier Zunz, Making America Corporate, 1870-1920 (Chicago, 1990).

${ }^{3}$ Robert A. Nisbet, The Quest for Community (New York, 1953); Maurice R. Stein, The Eclipse of Community: An Interpretation of American Studies (Princeton, 1960); Arthur J. Vidich and Joseph Bensman, Small Town in Mass Society: Class, Power and Religion in a Rural Community (Princeton, 1968); Roland L. Warren, The Community in America (Chicago, 1963); and Melvin Webber, "Order in Diversity: Community without Propinquity," in Cities and Space, ed. Lowdon Wingo (Baltimore, 1963), 23-54. For a critique and summary see Albert Hunter, "Persistence of Local Sentiments in Mass Society," in Handbook of Contemporary Urban Life, ed. David Street (San Francisco, 1978), 133-62.

${ }^{4}$ John Kenneth Galbraith, The New Industrial State (Boston, 1971); Paul Kantor with Stephen David, The Dependent City: The Changing Political Economy of Urban America (Glenview, IL, 1988), 164-70; John Mollenkopf, The Contested City (Princeton, 1983); Michael Storper, "Toward a Structural Theory of Industrial Location," in John Rees, Geoffrey J. D. Hewings, and Howard A. Stafford, eds., Industrial Location and Regional Systems (New York, 1981), 17-41; Thomas Stanback and Thierry Noyelle, The Economic Transformation of American Cities (Totowa, NJ, 1983); Allen J. Scott and Michael Storper, eds., Production, Work, Territory: The geographical anatomy of industrial capitalism (Boston, 1986). 
connections with the changing national and world economy. I use quantitative measures to define contrasting regional and network orientations that reflect the relative localization or nationalization of community economic life. Between 1900 and 1950, Seattle and Portland were both regional capitals. Since the 1950 s, however, Seattle has assumed functions that reach beyond the Pacific Northwest for inputs and markets. While Portland has pursued its traditional role, and even gained ground as a regional metropolis, Seattle has grown into a network city involved in the long-distance transfer of goods, services, and ideas.

The character of civic enterprise shapes this divergence. Faced with the same economic environment between 1955 and 1970, Portland responded with hesitancy, while Seattle acted with greater flexibility and initiative. Comparisons of parallel public decisions in the two cities allow us to weigh the effects of government institutions and political values on growth. For the crucial years around 1960, Seattle's tendency to make network-oriented choices can best be explained by studying the decision-making styles grounded in each city's political culture. ${ }^{5}$

A century ago, Portland and Seattle had an equal partnership in the Pacific Northwest. In the mercantile model of urban growth suggested by Richard Wade and elaborated by James Vance, they were points of entry for capital and labor in a developing frontier. ${ }^{6}$ Portland's eight-year head start as an American settlement-1843 versus 1851-gave it an initial edge in trade with gold-rush California, but both cities soon developed as importers or suppliers of manufactured goods and processed foods and as exporters of raw materials within a commercial and financial system dominated by San Francisco. ${ }^{7}$ By the time transcontinental railroads reached the Northwest, Portland's jump on Seattle was down to the single year between 1883 and 1884, although Seattleites waited until the early 1890s for fully competitive service.

${ }^{5}$ The distinction between structural and cultural determinants of community decisionmaking follows Michael Aiken and Robert R. Alford, "Comparative Urban Research and Community Decision-Making," in Willis D. Hawley and Frederick M. Wirt, eds., The Search for Community Power, 2d ed. (Englewood Cliffs, NJ, 1974), 274, and J. Rogers Hollingsworth and Ellen Jane Hollingsworth, Dimensions in Urban History: Historical and Social Science Perspectives on Middle-Size American Cities (Madison, 1979), 10-12.

${ }^{6}$ Richard C. Wade, The Urban Frontier: The Rise of Western Cities, 1790-1830 (Cambridge, MA, 1959); James E. Vance, Jr., The Merchant's World: The Geography of Wholesaling (Englewood Cliffs, NJ, 1970). Nineteenth-century Portland and Seattle can also be viewed as gateway cities in the sense developed in William Cronon, Nature's Metropolis: Chicago and the Great West (New York, 1991).

${ }^{7}$ Rodman Paul, Mining Frontiers of the Far West, $1848-1890$ (New York, 1963); D. W. Meinig, "American Wests: Preface to a Geographical Interpretation," Annals of the Association of American Geographers 62 (June 1972): 164; E. Kimbark MacColl with Harry H. Stein, Merchants, Money and Power: The Portland Establishment, 1843-1913 (Portland, 1988), 4-41; Norbert MacDonald, Distant Neighbors: A Comparative History of Seattle E Vancouver (Lincoln, 1987), 12 14. 
In the common version of the history of the Northwest, the Klondike gold rush of 1897 permanently upset the commercial balance between cities. Through a combination of boosterism, luck, and previous trading connections, Seattle made itself the entrepôt for the Far North. Portland and other West Coast cities had equal ambitions, but publicist Erastus Brainerd and the Seattle Chamber of Commerce identified Seattle with Alaska in the public mind ${ }^{8}$ Captured initially in the flush times, the story goes, Alaska business stayed in the pocket of Seattle merchants, bankers, and boat builders, and triggered an inevitable process of economic agglomeration that pushed Seattle's population past Portland by 1910 and kept it in the lead. ${ }^{9}$ As early as 1921, historians such as Ezra Meeker perceived that "without Alaska Washington would not now have attained the commanding development that is her pride." Murray Morgan said it even more directly: "In Seattle, gold spurred growth, and growth battened on growth." 10

In both thematic and chronological coverage, the story, as outlined, is typical of historical explanations of the relative fortunes of American cities. It treats differential urban growth as the product of an intraregional competition that was over by the twentieth century. On closer examination, however, the Portland-Seattle case does not match the standard model as closely as supposed. The recent experience of the two cities demonstrates the continued volatility of urban fortunes within a regional context, as new sources and avenues of growth have emerged with the expanding scale of economic activity. The case invites an alternative explanation for differential urban growth that emphasizes national and international connections, in addition to regional roles. The history of the two cities reconfirms the importance of specific events and choices, but the point of divergence lies sixty years closer to the present than often thought. In addition, many of the crucial decisions have involved the public, rather than the private, sector.

8 Jeannette Paddock Nichols, "Advertising and the Klondike," Washington Historical Quarterly 13 (January 1922): 20-26; Norbert MacDonald, "Seattle, Vancouver, and the Klondike," Canadian Historical Review 49 (September 1968): 234-46; Murray Morgan, Skid Road: An Informal Portrait of Seattle, rev. ed. (Sausalito, CA, 1971), 156-63.

${ }^{9}$ WPA Writers' Program, Washington: A Guide to the Evergreen State (Tacoma, 1941), 218 20; Howard H. Martin, "Urban Patterns of Western Washington," in Otis W. Freeman and Howard H. Martin, eds., The Pacific Northwest: An Overall Appreciation (New York, 1954), 45962; Edwin J. Cohn, Jr., Industry in the Pacific Northwest and the Location Theory (New York, 1954), 26; Constance McLaughlin Green, American Cities in the Growth of the Nation(New York, 1965), 177-79; Gordon B. Dodds, The American Northwest (Arlington Heights, IL, 1986), 134-35; and Carlos A. Schwantes, The Pacific Northwest: An Interpretive History (Lincoln, 1989), 195-98.

${ }^{10}$ Ezra Meeker, Seventy Years of Progress in Washington (Seattle, 1921), 328; Murray Morgan, Puget's Sound: A Narrative of Early Tacoma and the Southern Sound (Seattle, 1979), 301. Also see the treatment of Portland in Roger Sale, Seattle Past to Present (Seattle, 1976), 50-93, and MacDonald, Distant Neighbors, 58, 70. 
The "Alaska thesis" of Seattle's ascendancy fits within the common historical model of interurban competition in the nineteenth-century United States. Baltimore and Philadelphia, St. Louis and Chicago, and scores of other urban rivals provide comparable stories in which active and foresightful entrepreneurs in one city capitalized on commercial opportunities potentially available to both. In turn, the trade of the newly acquired hinterland supported further growth of the successful city and increased its competitive advantage in future rivalries. The model is especially apt for the era of continental expansion, when the progress of settlement involved the allocation of newly opened frontiers among new commercial centers. ${ }^{11}$ Indeed, historical studies of urban rivalries and urban imperialism mirror the nineteenth-century understanding of urban growth as the product of territorial control of resources and trade. ${ }^{12}$

A spatially-rooted explanation of differential urban growth also matches the basic assumptions of central place theory. One of the key models in modern quantitative geography, central place theory, was developed in Germany in the 1930s, introduced in the United States in the 1940s, and tested against American evidence in the 1950s and 1960s. The theory argues that there is a correspondence between the size of a city, the variety of functions it performs for a surrounding hinterland, and the size or purchasing power of that hinterland. The wider a city's spatial reach, the broader its range of businesses and the larger its population. A city that captures a new customer base (such as Alaska) or enjoys a rapidly developing hinterland (such as the Columbia Plateau) positions itself for economic diversification and growth in the level of economic activity. The final result in a developing region is a nested hierarchy of towns and hinterlands that builds successively from crossroads stores through small towns to comprehensive regional centers. ${ }^{13}$

The structured propositions of central place theory recognize the resources and demands of a city's hinterland as the essential engine of that

${ }^{11}$ For an introduction to the literature on inter-urban competition and urban imperialism, see Charles N. Glaab, "Historical Perspective on Urban Development Schemes," in Social Science and the City, ed. Leo F. Schnore (New York, 1968), 197-219.

12 Wade, Urban Frontier, 322-36; Carl Abbott, Boosters and Businessmen: Popular Economic Thought and Urban Growth in the Antebellum Middle West (Westport, CT, 1981), 198-208; Charles N. Glaab and A. Theodore Brown, A History of Urban America, 2d ed. (New York, 1976), 59-65; J. Christopher Schnell and Katherine B. Clinton, "The New West: Themes in Nineteenth Century Urban Promotion," Bulletin of the Missouri Historical Society 30 (January 1974): 75-88.

${ }^{13}$ Walter Christaller, Central Places in Southern Germany (Englewood Cliffs, NJ, 1966); August Lösch, The Economics of Location (New Haven, 1954); Edward Ullman, "A Theory of Location for Cities," American Journal of Sociology 46 (May 1941): 835-64; Brian J. L. Berry and Allan Pred, Central Place Studies: A Bibliography of Theory and Applications (Philadelphia, 1965); Brian J. L. Berry, The Geography of Market Centers and Retail Distribution (Englewood Cliffs, NJ, 1967). 
city's growth. ${ }^{14}$ In historical terms, the process of interurban competition has determined relative positions in the hierarchy of central places. For newly settled frontiers such as the Pacific Northwest, where each ambitious town started nearly equally, it requires historical analysis to understand how Seattle eclipsed Everett, or how Portland squeezed out Oregon City. This regional approach to urban growth has been particularly congenial to American urban historians because it emphasizes local decisions and sources of information, and is compatible with practicable case studies. It also ties the subfield of urban history to the wide historical interest in the expansion of the continental resource frontier. ${ }^{15}$

An alternative model that emphasizes extra-regional networks as key determinants of urban growth may offer greater relevance to the processes of urban development in the twentieth century, which has been marked by basic changes in the sectoral composition and spatial patterns of economic activity. Several historians who have taken on topics with broad spatial and temporal sweep have described dual urban systems in which a set of regionally based cities co-exists with a second set of cities oriented to national or transnational networks. Studying late imperial China, G. William Skinner found that one hierarchy of towns and cities served regional trading needs with few connections outside their local hinterlands. The hierarchy developed from the bottom up with the expansion of local and provincial commerce in accord with the assumptions of central place theory. A second hierarchy of administrative centers, in contrast, was created from the top down by imperial agents and functioned as a single network of centers for control and information transmission. ${ }^{16}$ Edward W. Fox divided premodern France into two sub-areas and urban systems based on different patterns of exchange. Central and interior France was a territorial society organized around local trade between provincial cities and regional agricultural hinterlands. The commercial society of the west-

${ }^{14}$ Although they start with large metropolitan centers rather than small towns, functional classifications of American cities have shared an interest in the regional sources of urban growth. Otis Dudley Duncan et al., Metropolis and Region (Baltimore, 1960) described a national urban hierarchy with a handful of truly national cities and a second tier of eight "regional metropolises" including Portland and Seattle. This second group is characterized by its special dependence on commercial and financial services performed for regional hinterlands. More recently, Thomas Stanback and Thierry Noyelle, in The Economic Transformation of American Cities, identified nineteen "regional diversified advanced service centers" that again include Seattle and Portland. The economies of such cities are dominated by regionally oriented transporation, utility, retail, banking, and wholesaling services.

${ }^{15}$ Carl Abbott, "Frontiers and Sections: Cities and Regions in American Growth," in Howard Gillette, Jr. and Zane L. Miller, eds., American Urbanism: A Historiographic Review (Westport, CT, 1987), 271-90.

${ }^{16}$ G. William Skinner, "Urban Development in Late Imperial China" and "Cities and the Hierarchy of Local Systems," both in The City in Late Imperial China, ed. G. William Skinner (Stanford, 1977), 3-27, 275-352. 
ern coast, in contrast, was dominated by Atlantic seaports tied more closely to interregional and international flows of goods than to their own backcountry. Bordeaux and Nantes co-existed with interior cities in the same political unit, but also participated in a network of trading cities that extended from Amsterdam and London to Lisbon, Barcelona, and Naples. ${ }^{17}$

In The Making of Urban Europe, Lynn Lees and Paul Hohenberg elaborated Fox's idea of regional and commercial systems as a major explanatory concept. They argued that western European urbanization produced parallel systems that coexisted in time and often in space. Cities in the central place system were rooted in a close relationship with their agricultural environs, expressed indigenous or provincial culture, and tied the locality to the state through a defined hierarchy of towns and cities. Network cities took their life from long-distance commerce and served as "centers, nodes, junctions, outposts, and relays" within complex sets of economic and social linkages that crossed political borders. They transmitted values and ideas from one culture to the next. Lees and Hohenberg have presented the two systems not as exclusive categories but as heuristic concepts that focus attention on one or the other aspects of urban growth. Major cities, indeed, could fill roles simultaneously in both regional and network systems. ${ }^{18}$

Historians of United States cities have sporadically stressed the importance of extraregional connections. In his classic study, The Rise of New York Port, Robert G. Albion argued that New York's early roles in coastal shipping, trans-Atlantic trade, and wholesaling were more important than its capture of a regional hinterland. For the twentieth century, Roger Lotchin and Gerald Nash have focused attention on the ways in which federal spending and investment in federal facilities functioned as sources of rapid growth in western cities. Other historians of sunbelt cities have also begun to examine international connections during the postwar decades. ${ }^{19}$

Extra-regional sources of urban growth have received theoretical attention in the social sciences. Geographer Allan Pred has offered empirical

${ }^{17}$ Edward W. Fox, History in Geographic Perspective: The Other France (New York, 1971).

${ }_{18}$ Paul Hohenberg and Lynn H. Lees, The Making of Urban Europe, 1000-1950 (Cambridge, MA, 1985). Also see Eugene Genovese and Leonard Hochberg, eds., Geographic Perspectives in History (London, 1989).

${ }^{19}$ Robert Greenhalgh Albion, The Rise of New York Port: 1815-1860 (New York, 1939); Roger W. Lotchin, Fortress California, 1910-1961: From Warfare to Welfare (New York, 1992); Gerald D. Nash, The American West Transformed: The Impact of the Second World War (Bloomington, $19 \stackrel{\rightarrow}{\rightarrow}$ Spencer C. Olin, "Globalization and the Politics of Locality: Orange County, California in the Cold War Era," Western Historical Quarterly 22 (May 1991): 143-62; Carl Abbott, "International Cities in the Dual Systems Model: The Transformations of Los Angeles and Washington," Urban History Yearbook No. 18 (Leicester, ENG, 1991). 
support for a model of urban growth that parallels the historical idea of the dual system, arguing that central place theory is far too limited for understanding the wide ranging connections of modern cities. In Pred's "asymmetric" model, a city's transactions with its regional hinterland are likely to be less important for its future than its unpredictable and idiosyncratic set of extra-regional connections. To support his argument, he points to the large proportion of jobs in every major city now controlled by multi-locational businesses and government organizations. A detailed, empirical description of the corporate control patterns of Seattle, Portland, and four other western cities as of 1974-1975 shows that extra-regional ties equal or outweigh those within traditional hinterlands. ${ }^{20}$

Pred's data are often cited by an emerging school of urban analysis that emphasizes a city's role in the global economy as the prime determinant of local economic change. In particular, fundamental changes in the world economic system during the 1970s have created a "new international division of labor" that has established a new and controlling context for urban growth programs. ${ }^{21}$ In specific applications, Joe Feagin has described twentieth-century Houston as being tied to international markets and multinational corporations through decisions of Detroit auto executives, congressional committees, and foreign oil producers. Edward Soja and his co-workers have detailed the transition of Los Angeles from a regionally-based metropolis, oriented to domestic markets, to "a global capitalist city of major proportions" that participates fully in the finance and production networks of the Pacific Rim. ${ }^{22}$

These alternative conceptions of regional and network cities help to define specific questions about the comparative development of twentieth century Seattle and Portland. Both cities entered the century having developed after two generations into regional centers for Puget Sound and the Columbia Basin. The common understanding of Northwest history suggests that both have retained their regional roles, but that Seattle has

${ }^{20}$ Allan Pred, City-Systems in Advanced Economies (New York, 1977), 98-165.

${ }^{21}$ Doreen Massey, The Spatial Division of Labor (London, 1984); David Harvey, The Urbanization of Capital (Baltimore, 1985); Joe R. Feagin and Michael Peter Smith, "Cities and the New International Division of Labor," in The Capitalist City, ed. Joe R. Feagin and Michael Peter Smith (Oxford, ENG, 1987), 3-36; Jeffrey Henderson and Manuel Castells, eds., Global Restructuring and Territorial Development (London, 1987); John R. Logan and Harvey L. Molotch, Urban Fortunes: The Political Economy of Place (Berkeley, 1987); Mark Gottdiener and Joe R. Feagin, "The Paradigm Shift in Urban Sociology," Urban Affairs Quarterly 24 (December 1988): 163-87; Robert A. Beauregard, ed., Economic Restructuring and Political Response (Newbury Park, CA, 1989).

22 Joe R. Feagin, "The Global Context of Metropolitan Growth: Houston and the Oil Industry," American Journal of Sociology 90 (May 1985): 1204-30; and Joe R. Feagin, Free Enterprise City: Houston in Political-Economic Perspective (New Brunswick, NJ, $19 \overbrace{}^{\sim} \rightarrow$ Edward Soja, Rebecca Morales, and Goetz Wolff, "Urban Restructuring: An Analysis of Social and Spatial Change in Los Angeles," Economic Geography 59 (April 1983): 195-230. 
made a better job of it, edging further ahead until it has left Portland behind. The suggestion that Seattle may have grown by gaining new trans-regional network functions, however, provides an alternative framework for understanding change within an urban system. A variety of accessible quantitative data allow a structured evaluation of Seattle's relative success.

In 1900, the Twelfth Census counted 9,555 more Portlanders than Seattleites. Eighty years later, Seattle's margin over Portland was either 365,000 (using Standard Metropolitan Statistical Areas [SMSA]) or 795,000 (using Consolidated Metropolitan Areas). For the years between, the changing population ratio provides a standardized measure that directly reflects the relative growth of the two cities (see Table 1; tables begin on p. 320). The first decade of the twentieth century shows the expected surge for Seattle, with carry-over into the 1910s. Between 1920 and 1950, however, the two cities grew at the same pace. Not until the 1950s and 1960s did Seattle began again to outpace Portland. The pattern since 1970 depends on the chosen definition for the Seattle and Portland metropolitan areas. Use of Consolidated Metropolitan Areas, which adds Tacoma to Seattle, shows Portland losing more ground after 1970. Comparison of growth within 1960 SMSA boundaries, however, shows relatively slower growth for Seattle in the 1970s, followed by recovery in the 1980s.

This aggregate population comparison directs the search for critical turning points in the Seattle-Portland rivalry to the 1950s and 1960s. Information on the structure of the two metropolitan economies supports the same conclusion by showing significant changes in the sources of economic growth for Seattle, but not for Portland, after 1950.

Apart from the Alaskan bonanza, Seattle and Portland retained more structural similarities than differences between 1900 and 1920. Both benefited from the shift of the American timber industry to the Northwest and from an agricultural boom in the Columbia Basin that was triggered by new railroad lines, private and public irrigation projects, stock raising, and dryfarming. ${ }^{23}$ Both cities' bankers controlled roughly equal amounts of capital when new federal reserve banks were located in $1913 .{ }^{24}$ Both

${ }^{23}$ D. W. Meinig, The Great Columbia Plain: A Historical Geography, 1805-1910 (Seattle, 1968); John Fahey, The Inland Empire: Unfolding Years, $1879-1929$ (Seattle, 1986); Thomas R.Cox, Mills and Markets: A History of the Pacific Coast Lumber Industry to 1900 (Seattle, 1974); Robert E. Ficken, The Forested Land: A History of Lumbering in Western Washington (Seattle, 1987); James O. Oliphant, On the Cattle Ranges of the Oregon Country (Seattle, 1968); and Dodds, American Northwest, 137-48.

${ }^{24}$ In 1913, national banks in Seattle had a capital stock surplus of $\$ 5,560,000$ and in Portland, $\$ 6,675,000$. See Richard Franklin Bensel, Sectionalism and American Political Development, 1880-1980 (Madison, WI, 1984), 426-31. Citing a different measure, Dorothy O. Johansen and Charles M. Gates, Empire of the Columbia: A History of the Pacific Northwest (New York, 1957), 435, report that national banking resources in 1909 totaled $\$ 38$ million for Seattle and $\$ 32$ million for Portland. 
downtowns experienced building booms to provide office space for commercial, financial, and professional service sectors. Successful international expositions in 1905 (Portland's Lewis and Clark Centennial Exposition and Oriental Fair) and 1909 (Seattle's Alaska-Yukon-Pacific Exposition) symbolized the cities' arrivals as mature communities that could command the respectful attention of easterners. ${ }^{25}$

Given the similar roles of the two cities, Seattle's more rapid growth tied directly to the development of its hinterland. For comparative analysis, Portland's primary hinterland is defined as Oregon and three adjacent counties in southwestern Washington, with southwestern Idaho as its secondary hinterland. Seattle's primary hinterland is the remainder of Washington, while Alaska, the Idaho panhandle, and western Montana are its secondary hinterland. ${ }^{26}$ As an estimate of effective market size, population is weighted at 1.0 in the primary hinterlands and at 0.5 in the secondary hinterlands, where other cities competed for market share (see Table 2). Between 1900 and 1920, Seattle's trading region grew more rapidly than Portland's, reflecting the development of Alaska and the Columbia Plateau and the climax of activity in the northern Rocky Mountain mining region. The completion of additional transcontinental railroads in 1893 and 1909 also helped Seattle cut into Portland's business in eastern Washington. The Seattle:Portland population ratio increased by 34 percent over the two decades while the comparable hinterland ratio increased by 20 percent (see Table 2, Column 1). If the populations of the two cities themselves are excluded from the hinterland totals, the ratio increased by 25 percent (see Table 2, Column 2).

${ }^{25}$ Carl Abbott, Portland: Planning, Politics and Growth in a Twentieth Century City (Lincoln, 1983), 33-70; George Frykman, "The Alaska-Yukon-Pacific Exposition, 1909," Pacific Northwest Quarterly 53 (July 1962): 89-99; Sale, Seattle, 78-86, 92.

${ }^{26}$ Portland's primary hinterland is defined as Oregon plus Clark, Cowlitz, and Skamania counties, Washington. Seattle's primary hinterland is defined as the remainder of Washington. Portland's secondary hinterland is Ada, Adams, Boise, Camas, Canyon, Elmore, Gem, Gooding, Owyhee, Payette, Twin Falls, and Washington counties, Idaho. Seattle's secondary hinterland is Alaska; Benewah, Bonner, Boundary, Clearwater, Idaho, Kootenai, Latah, Lewis, Nez Perce, and Shoshone counties, Idaho; and Beaverhead, Broadwater, Cascade, Deer Lodge, Flathead, Gallatin, Glacier, Granite, Lewis and Clark, Lincoln, Madison, Meagher, Mineral, Missoula, Park, Pondera, Powell, Ravalli, Sanders, Silver Bow, Teton, and Toole counties, Montana. The allocation of these territories is based on patterns of rail and water transportation, retail trade, and newspaper circulation. Several studies are useful for defining the outer limits where the Seattle and Portland hinterlands have shaded into those of San Francisco, Salt Lake City, and Minneapolis-St. Paul. These include John R. Borchert, America's Northern Heartland (Minneapolis, 1987); Mildred Hartsough, The Twin Cities as a Metropolitan Market (Minneapolis, 1925); Chauncy Dennison Harris, Salt Lake City: A Regional Capital (Chicago, 1940); D. W. Meinig, "The Mormon Culture Region: Strategies and Patterns in the Geography of the American West," Annals of the Association of American Geographers 55 (1965): 191-220; and A. Philip Andrus et al., Seattle (Cambridge, MA, 1976), 1-3. 
There was little change in the standing of the two cities between 1920 and 1950. Portland drew closer to Seattle in population in the 1920s, held its gains in the 1930s, and slipped only as far as its relative position of 1920 during the turbulent 1940s. Data on industrial structure support the picture of regional stability. Regionally-based manufacturing makes direct and essential use of regional resources and raw materials. ${ }^{27}$ Although the basis for data compilation changed in 1930 and again in 1940, the Seattle:Portland ratios in Table 3 suggest that such industries accounted for a stable proportion of total employment in each city from 1920 to 1940. War production jobs and wartime growth were also comparable. ${ }^{28}$ As late as the 1950s, outside observers thought that the two cities competed on an equal basis for the trade of the Pacific Northwest, with Portland gaining shipping and wholesaling at the expense of Seattle, and Seattle building a more diversified manufacturing base..$^{29}$

Another indicator of regional relationships is the extent to which economic activity and population concentrate in a single "primate" city. High concentration may reflect both the absence of strong secondary cities, as in lesser developed nations, and the "overdevelopment" of a dominant city through participation in trading systems or other exchange networks external to its regional hinterland, as with medieval Venice or modern Miami. ${ }^{30}$ Table 4 summarizes the standard Ginsburg Index of

${ }^{27}$ Regionally oriented manufacturing industries include lumber and wood products, paper and related products, foodstuffs, textile mills, furniture and related products, leather products, and primary metals. Metals are included because of the importance of local iron ore for small iron producing industries at the turn of the century and because of the role of regionally generated hydro-electric power as the essential resource input for aluminum production. The data were drawn from: Twelth Census of the United States, Vol. 8: Manufactures, Pt. 2: States and Territories and Special Reports: Occupations (Washington, DC); Thirteenth Census of the United States, Vol. 9: Manufactures: Reports by States (Washington, DC); Fourteenth Census of the United States, Vol. 4: Population: Occupations and Vol. 9: Manufactures: Reports for States (Washington, DC); Fifteenth Census of the United States, Vol. 4: Occupations by States (Washington, DC); Sixteenth Census of the United States: Characteristics of the Population, (Washington, DC), Table 51; Seventeenth Census of the United States: Characteristics of the Population (Washington, DC), Table 79; Eighteenth Census of the United States: Characteristics of the Population (Washington, DC), Table 12; Nineteenth Census of the United States: Characteristics of the Population (Washington, DC), Table 184; Twentieth Census of the United States: Detailed Population Characteristics (Washington, DC), Table 228.

${ }^{28}$ Carl Abbott, "Planning for the Home Front in Seattle and Portland, 1940-45," in The Martial Metropolis, ed. Roger Lotchin (New York, 1984), 163-89.

${ }^{29}$ John Gunther, Inside U.S.A. (New York, 1947), 92; and Neil Morgan, Westward Tilt: The American West Today (New York, 1963), 210-12.

${ }^{30}$ Brian J. L. Berry, "City Size Distribution and Economic Development," Economic Development and Cultural Change 9 (July1961): 573-87; Clyde Browning, "Primate Cities and Related Concepts," in Urban Systems and Economic Development, ed. F. R. Pitts (Eugene, OR, 1962); Brian J. L. Berry and Frank E. Horton, Geographic Perspectives on Urban Systems: With Integrated Readings (Englewood Cliffs, NJ, 1970), 64-93; Michael Timberlake, ed., Urbanization in the World-Economy (Orlando, FL, 1985). 
urban primacy, calculated by dividing the population of a region's largest city by the combined population of its four largest cities. An index that approaches 1.0 indicates that the largest city far overshadows its nearest rivals. An index of .50 or less shows the presence of substantial secondary cities, a pattern that is characteristic of developed economies. ${ }^{31}$

The primacy indices for Portland and Seattle are striking for their stability between 1920 and 1950. Just as neither metropolis gained or lost population relative to the other, so neither gained nor lost significantly, relative to the secondary cities in its hinterland. Seattle's lower index reflects the size of its hinterland cities of Tacoma, Spokane, and Butte, which outranked Boise, Eugene, and Salem until after World War II. By implication, Seattle's well-developed hinterland offered a wide range of opportunities for growth as a regional city.

Portland's strong competitive showing in the 1920s and 1930s was tied to continued growth in its farming hinterland in Oregon and southern Idaho. In contrast, the mining regions of Alaska, northern Idaho, and Montana were stagnating (see Table 2). The Seattle:Portland ratios of hinterland population declined by 13 to 17 percent between 1920 and 1940, showing the more rapid growth of Portland's trading zone. Data available since 1930 allow the population totals to be weighted by state per capita personal income, which gives a closer approximation of hinterland purchasing power. The weighting alters the individual ratios but not the trend (see Table 2, Columns 3-4).

After a century of relatively stable competition, the regional sources of Seattle's advantage over Portland began to erode in the 1950s. If anything, Portland, rather than Seattle, reaped the greatest benefit from regional development and regionally-oriented activities. Even though Seattle's population margin over Portland grew from 20 percent in 1950 to 41 percent in 1970 , the two hinterlands grew at essentially the same pace (Table 2). Seattle's increasing primacy after 1950 suggests that it has become less dependent on regional connections. Portland's decreasing primacy, in contrast, is caused by the more rapid development of its hinterland with resulting opportunities for regional trade and services.

Trends in specific industrial sectors support the conclusion that Portland, rather than Seattle, benefited most from regional functions after 1950. Before World War II, for example, Seattle's wholesale business was half again as great as Portland's. Seattle's lead shrank to a few percentage points in the 1940s and 1950s and disappeared completely in the 1960s and 1970s. Although a portion of wholesale trade involved log and lumber

31 Norton Ginsburg, Atlas of Economic Development (Chicago, 1961); Kingsley Davis, World Urbanization, 1950-1970, Vol. 1, Basic Data for Cities, Countries and Regions (Berkeley, 1976); Pamela Barnhouse Walters, "Systems of Cities and Urban Primacy: Problems of Definition and Measurement," in Urbanization, ed. Timberlake, 63-85. 
brokerage for national markets, the majority represented regional distribution. ${ }^{32}$ Most federal employment outside the Department of Defense similarly involves local services such as mail delivery and veterans' assistance or regional resource management through the Forest Service, National Park Service, Bonneville Power Administration, and similar agencies. Despite Seattle's status as a federal regional center, the same proportion of Portlanders and Seattleites worked in such jobs as of $1980 . .^{33}$

The most obvious contrast with Seattle's stable or declining regional role was the rapid growth of aerospace manufacturing employment as Boeing captured the dominant share of commercial jetliner production for national and overseas airlines. After the failure of the Stratocruiser in the immediate postwar decade, Boeing introduced the highly successful 707 in 1958, following with the 727, the 737, and the 747 , which began to roll off production lines in Everett in 1970. Aircraft manufacturing jobs in metropolitan Seattle increased steadily from 1949 to 1958. For the next fifteen years, however, Boeing's employment fluctuated widely. Three quick cycles of boom and bust culminated in the deep "Boeing depression" of 1969-1971, when the corporation's local employment fell from 105,000 to 38,000 . In addition, Boeing procured only 10 percent of its processing inputs from the Seattle area during the 1960s, limiting its capacity to stimulate local economic diversification, though shielding the city from multiplier effects of production slowdowns. The major developmental impact of Boeing, in short, was felt with national rearmament in the early 1950s, rather than in the booming 1960s. ${ }^{34}$

Equally important in the long run were additional changes that tied Seattle into national and international networks. The growth sectors included tourism, higher education, research and development, finance, and foreign trade. In concert with Boeing's expansion in response to world markets, a set of public decisions in Seattle between 1955 and 1970 confirmed its participation in a variety of long-distance networks. The

32 J. Dennis Lord, "Shifts in the Wholesale Trade Status of U. S. Metropolitan Areas," Professional Geographer 36 (1984): 51-63; Morgan, Westward Tilt, 210. The Seattle:Portland ratios for wholesale sales were 1.50 in 1930; 1.42 in 1940; 1.05 in 1949; 1.04 in 1958; .90 in 1967; and .86 in 1977. Data are from Fifteenth Census of the United States, Distribution, Vol. II: Wholesale Distribution (Washington, DC); Census of Business: 1939, Vol. II: Wholesale Trade (Washington, DC); County and City Data Books, 1952-77; State and Metropolitan Area Data Book, 1982.

${ }^{33}$ U. S. Office of Personnel Management, Federal Civilian Workforce Statistics: Report of Employment by Geographic Area: December 31, 1980 (Washington, DC).

${ }^{34}$ Rodney A. Erickson, "The Regional Impact of Growth Firms: The Case of Boeing, 1963-68," Land Economics 50 (May 1974): 127-36; and Rodney A. Erickson, "The Spatial Pattern of Income Generation in Lead Firm, Growth Area Linkage Systems," Economic Geography 51 (January 1975): 17-26; U. S. Arms Control and Disarmament Agency, A Case Study of the Effects of the Dyna-Soar Contract Cancellation upon Employees of the Boeing Company in Seattle, Washington (U.S. ACDA Publication No. 29, 1965); Laurence S. Kuter, The Great Gamble: The Boeing 747 (University, AL, 1973). 
remainder of this essay explores these decisions and their results in comparison with Portland.

Although the numbers point to the 1950s as the decade when the fortunes of the two cities began to diverge, direct comparison of their governmental capacity would have offered little encouragement for an ambitious Seattle. Both cities had fiscally conservative "caretaker" governments that placed greatest emphasis on the smooth delivery of routine services. ${ }^{35}$ Portland mayors Earl Riley (1941-1948), Fred Peterson (1953-1956), and Terry Schrunk (1957-1972) maintained close ties with important local market businesses. Seattle mayors Arthur Langlie (1938-1942), William Devin (1942-1952), and Gordon Clinton (1956-1964) were even more clearly the picks of the local economic establishment. Reform-minded mayors who entered office hoping to activate local government-Dorothy Lee in Portland (1949-1953) and Alan Pomeroy in Seattle (1952-1956) found themselves frozen out of the action by the downtown establishment and City Hall cronies. ${ }^{36}$

Both city administrations were also buffered against vigorous central direction. Individual elected officials and bureaucrats constituted functional fiefdoms within each city government. Under Portland's commission charter, the mayor and each of four independently elected city commissioners managed separate sets of city departments. Seattle had achieved the same fragmentation by institutionalizing a system in which the chairs of city council committees controlled the budgets for specific functional areas and dominated council discussions with expertise and access to specialized information. The result, as Edward Banfield noted in Big City Politics, was to force any analysis of Seattle politics to start with the question: "Anybody in Charge?"37

Despite these formal similarities, Seattle mounted a series of public initiatives between 1958 and 1968 that Portland was unable to match. Community efforts assured a successful world's fair, developed convention and sports facilities, provided essential infrastructure to support a growing

$\rightarrow$ Oliver P. Williams, "A Typology for Comparative Local Government," Midwest Joumal of Political Science 5 (1961): 150- 64; Oliver P. Williams and Charles R. Adrian, Four Cities: A Study of Comparative Policy Making (Philadelphia, 1963). Caretaker governments contrast with those that actively pursue economic development, provide a wide range of amenities, or try to redistribute resources and services among groups and neighborhoods.

${ }^{36}$ The results of electoral politics in Seattle are discussed in Edward C. Banfield, Big City Politics: A Complete Guide to the Political System of Atlanta, Boston, Detroit, El Paso, Los Angeles, Miami, Philadelphia, St. Louis, Seattle (New York, 1965), 132-45; James Halpin, "Our Musty, Crusty City Council," Seattle Magazine, May 1965, 12-16, 46-48; and David Brewster, "The Making of a Mayor, 1969," Seattle Magazine, May 1969, 21-25,47-50. For Portland, see E. Kimbark MacColl, The Growth of a City: Power and Politics in Portland, 1915-1950 (Portland, 1979), 60960, and Paul C. Pitzer, "Dorothy McCullough Lee: The Successes and Failures of 'Dottie-DoGood," Oregon Historical Quarterly 91 (Spring 1990): 5-42.

${ }^{37}$ Banfield, Big City Politics, 132. 
metropolis, and revitalized the port. The cumulative effect was to move Seattle into new roles in long range networks of exchange. Over the same decade, Portland faced similar opportunities and attempted parallel projects but failed to act effectively to promote economic growth.

Contemporary observers commented on the contrasting approaches to public business. Journalists such as Neil Morgan and Neil Pierce and scholars such as Earl Pomeroy and Dorothy Johansen all perceived different spirits of public and private enterprise. "Unlike Seattle, which is in its own promotional vocabulary a 'go-ahead' city," Johansen wrote in 1967, "Portland moved in 1965 as slowly and deliberately as it did in 1865, and there remains considerable sentiment . . . to 'keep things as they are.' "38 These styles of public action expressed distinct valuations of community entrepreneurship. Each city inclined to a particular way of doing business by a well-established understanding of acceptable behavior and by institutions that codified those customs and traditions. Assumptions about the proper way to carry out the public business conditioned specific responses to scale change in the American economy. Portland was process-centered, cautious, and localized. Seattle was project-centered, entrepreneurial, and expansive. While Seattleites built in anticipation of growing business, Portlanders judged facility needs by current demand and by the potential of purely local and regional markets. In the broadest sweep, Seattle leaders viewed the expansion of economic scale as an opportunity and measured their ambitions by Chicago, Philadelphia, and Pittsburgh. Portlanders viewed the expansion of economic networks as irrelevant or even threatening to stable commercial relationships. ${ }^{39}$

Different experiences with major expositions illustrate the contrast. The two cities began by competing not only for regional and national attention but also for the same date. Led by the Portland Chamber of Commerce, Oregonians decided in December 1954 to commemorate the centennial of statehood with a celebratory exposition in Portland in 1959. Within a few months, Seattleites began to explore a fifty-year follow-up to the Alaska-Yukon-Pacific Exposition of 1909. As second in line, Seattle reluctantly ceded 1959 to Portland and shifted its target to 1961 (later 1962). ${ }^{40}$

${ }^{38}$ Johansen and Gates, Empire of the Columbia, 564; Earl Pomeroy, The Pacific Slope: A History of Califormia, Oregon, Washington, Idaho, Utah, and Nevada (New York, 1965), 139; Neal Pierce, The Pacific States of America (New York, 1972), 215; Morgan, Westward Tilt, 212; Sale, Seattle, 189, 213.

${ }^{39}$ Central Association of Seattle, Annual Report for 1960- 61, Box 10, Dingwall Papers, University of Washington Manuscript Division, University of Washington, Seattle, Washington (hereafter Dingwall Papers).

${ }^{40}$ For Seattle, see Murray Morgan, Century 21: The Story of the Seattle World's Fair (Seattle, 1963); John M. Findlay, "The Off-center Seattle Center: Downtown Seattle and the 1962 World's Fair," Pacific Northwest Quarterly 80 (January 1989): 2-11; Cyrus Noe, "Innocence 
The parallels ended with the timing. The scope of the Seattle exposition grew steadily from a regional reaffirmation of the Alaska connection to "a means of recapturing prestige ... as the gateway to the Orient" and, finally, to the global theme of "the wonders of the 'space age' science" and the future of "Century 21," a newly created non-profit branch of the Washington State fair commission that managed the fair. ${ }^{41}$ The fair's advocates recruited strong business leadership and political backing in Olympia and used Century 21 to insulate their operations from local politics. The promoters tapped the city for $\$ 15$ million in site and building improvements, secured $\$ 7.5$ million from the State of Washington, and obtained $\$ 9$ million for federal participation. The federal commitment forced postponement to 1962, but it enabled fair chairman Joseph Gandy to argue successfully for designation as a world's fair by the Bureau of International Expositions. ${ }^{42}$ Official sanction also allowed the planners to attract international exhibits and to draw on the best national expertise, ranging from the Walt Disney organization to an advisory board representing the National Science Foundation, National Academy of Sciences, and American Association for the Advancement of Science. Reams of favorable publicity and 9,600,000 paid visits made it arguably the most successful of all postwar American world's fairs. The renovated site and buildings, about a mile north of downtown, became Seattle Center, with a science museum, renovated auditorium, and major convention facilities. Just as importantly, the fair symbolized Seattle's arrival as a national city and taught outsiders that the Northwest's metropolis started with an "S".43

Portland had preempted 1959 but lost its chance to upstage Seattle

Revisited: Twenty Years after the Fair," Pacific Northwest 16 (April 1982): 24-32; and substantial materials in the Dingwall Papers and the Joseph Gandy Papers, University of Washington Manuscripts Department, University of Washington, Seattle, Washington (hereafter Gandy Papers). The story of the Oregon Centennial Exposition must be pieced together from newspaper accounts and from the Oregon Centennial Commission Papers, Oregon Historical Society, Portland, Oregon (hereafter Commission Papers), the Ted Hallock Papers, Oregon Historical Society, Portland, Oregon (hereafter Hallock Papers), and the Anthony Brandenthaler Papers, Oregon Historical Society, Portland, Oregon (hereafter Brandenthaler Papers).

${ }^{41}$ Minutes of Board of Trustees, World Fair Corporation, 28 January and 22 July 1958, Box 14, Dingwall Papers; Design Standards Advisory Board, "Preliminary Site Plan Report," 1958, Box 13, Dingwall Papers.

42 Transcript of interview of Ewen Dingwall by John Findlay, 19 August 1985, Dingwall Papers (hereafter Dingwall interview); "Historical Features" file, Box 1, Gandy Papers; Minutes of Board of Trustees, World's Fair Corporation, 27 March 1958 and 30 October 1959, Box 14, Dingwall Papers.

43 "Report of the Century 21 Commission, State of Washington, 1961," Box 13, Dingwall Papers; and Dingwall interview. For typical discussions of the fair as a boost for Seattle, see Russell Lynes, "Seattle Will Never be the Same," Harpers, July 1962, 20-25; and Charles N. Stabler, "Seattle World's Fair Likely to be First One in 30 Years to Profit," Wall Street Journal (New York), 13 July 1962. 
by planning the Oregon Centennial Exposition on the cheap. While Seattle steadily broadened the scope and appeal of its effort, Portland whittled its vision to the comfortable model of local "pioneer days." Despite early national publicity and a small international trade fair, the celebration had little to attract Portlanders, let alone visitors from out of state. Planned initially to utilize a new Portland coliseum and convention center, the exposition had to turn to the Oregon legislature when the Portland facility bogged down in the city's neighborhood politics. The parsimonious state doled out \$2.6 million in two grudging installments in 1958 and 1959, barely in time to remodel a livestock exhibition hall into display space. Downstate jealousies were manifested in a penny-pinching Oregon Centennial Commission that determined to show an operating profit, and diverted effort to ancillary events around the state. Political conflicts between the state commission and newly elected Governor Mark Hatfield hobbled local managers in the last months of preparation. ${ }^{44}$ Portlanders themselves quickly learned to stay away from what turned out to be little more than an interminable county fair without the plum preserves and Future Farmers. The 900,000 paid admissions embarrassed civic leaders who had hoped for 5-7 million visitors. The event left a slightly improved facility for the privately operated Pacific International Livestock Exposition rather than any equivalent of Seattle Center. ${ }^{45}$

A delay in the construction of a coliseum and convention center handicapped the centennial exposition. As early as 1954, a mayor's advisory committee had recommended a Columbia River site for an exposition-arena campus that could accommodate the Pacific International stock show, as well as other events. In May 1954, Portland voters approved a charter amendment that created an Exposition-Recreation Commission and authorized an $\$ 8$ million bond issue. The assurance of funding brought the city's sectional conflicts into the open. Reports from the Planning Commission and Stanford Research Institute argued for a centrally located alternative. The leading site, in the view of downtown investors, was an under-utilized area south of the downtown-land that would later be incorporated into Portland's first urban renewal project. In October 1955, the Exposition-Recreation Commission voted three to two for the

${ }^{44}$ Stanford Research Institute, Study of the Economic Feasibility and Preliminary Planning Requirements for the Proposed Oregon Centennial Celebration, June 1955, Box 1, Accession Group 1603-1, Commission Papers; Final Report of Oregon Centennial Commission (draft, 1960), Box 2, Accession Group 1603, Commission Papers; Ted Hallock to John Simpson, 27 July 1959, Hallock Papers; transcript of KATU-TV news report by Tom McCall on Mark Hatfield's questions about Centennial Commission spending, Brandenthaler Papers; Lillie Sweetland (Centennial Commissioner) to the editor, Oregonian (Portland), 13 August 1958; Oregon Journal (Portland), 13 March and 4 April 1957; Oregonian (Portland), 5 October and 23 December 1958.

${ }^{45}$ Oregonian (Portland), 24 July and 5 August 1959; Final Report, Commission Papers. 
Columbia River location. The city council then refused, by one vote, to make available the necessary city land. The stalemate was broken by a successful initiative measure that restricted any coliseum to the east side of the Willamette River (an area that included the Columbia River shoreline). The city finally compromised with a location on the east bank of the Willamette River within view of downtown. The openness of the deliberations and Oregon's easy use of the voter-initiated referendum allowed different economic interests to derail the project in sequence. When finally built, the new coliseum was too small to compete for large national conventions; and, ironically, voters rejected expansion in 1962 as too risky. ${ }^{46}$

The differing fates of proposals for covered sports stadiums also revealed contrasting approaches to growth. Portland's proposed "Delta Dome" (named for its site in Delta Park near the Centennial Exposition grounds) would have been the nation's second covered multipurpose stadium. Despite strong backing from Mayor Terry Schrunk and other politicians, from newspapers, and from utility companies, Multnomah County bonds proposals for a Delta Dome failed in both May and November 1964, with substantial opposition in every part of the county ${ }^{47}$ In addition to their concerns about site access, many voters were unwilling to risk national competition by building a stadium without a previous commitment from a major league baseball franchise. ${ }^{48}$

Defeat at the polls opened the doors for city and suburban politicians to float competing proposals for a new site near the Columbia River, for suburban locations, and for expansion of existing facilities. Advocates of each scheme for new construction were able to veto the competition without being able to develop a coalition around their own proposal. ${ }^{49}$ Under heavy pressure from downtown hotels and retailers, the City of Portland

${ }^{46}$ Progress Notes on the Exposition-Recreation Center, 23 July 1956, Ormond Bean Papers, Oregon Historical Society, Portland, Oregon; statements on Exposition-Recreation Center by James Richardson, October 1955, and William Bowes, 25 October 1955, and report of Exposition-Recreation Commission to Mayor Terry Schrunk, 3 July 1957, all in Box 1, William Bowes Papers, Oregon Historical Society, Portland, Oregon; "Report on ExpositionRecreation Bonds, New Series," Portland City Club Bulletin 43 (2 November 1962).

47 "Report on Authorizing County Bonds to Construct a Covered Stadium," Portland City Club Bulletin 45 (23 October 1964); "Report on Multnomah Stadium Acquisition Bonds," Portland City Club Bulletin 47 (21 October 1966); Terry Schrunk to R. W. DeWeese, 31 August 1964, Box 1, Terry Schrunk Papers, Oregon Historical Society, Portland, Oregon (hereafter Schrunk Papers); Oregon Journal (Portland), 14 November 1964.

48 "Report . . . September-November 1964," opposition statement by Citizens Against Delta Dome, and "General Summary of Data Analysis on Delta Dome Election, November 1964," in Volunteers for Delta Dome Covered Stadium Papers, Oregon Historical Society, Portland, Oregon.

49 "Portlanders Confused on Stadium," Oregonian (Portland), 27 February 1966. Also, Oregonian (Portland), 8 January and 11 February 1966; and Oregon Journal (Portland), 10 February 1966. 
purchased an inadequate 28,000-seat stadium located on the downtown fringe from private owners in 1966. By committing Portland to an interim measure, the action killed hope of a new, nationally competitive facility. It also expressed a deep unwillingness to speculate on the long-term expansion of professional sports. The city maintained a venue for Triple-A baseball and high school football playoffs, but dropped off the list for major league baseball or football. ${ }^{50}$

Seattle started the 1960s with similar problems. Efforts to court the Cleveland Indians in 1964 foundered on inadequate facilities and lack of enthusiasm at City Hall. ${ }^{51}$ The commercial-civic elite incorporated a major stadium in the massive 1968 bond issue that voters approved under the rubric Forward Thrust. Use of a state-appointed Washington Stadium Commission to evaluate locations in the suburbs, near Seattle Center, and south of downtown, deliberately took the decision on site out of open politics. The appointment of Joe Gandy, the former president of the Century 21 corporation, kept the civic elite in control of the process. A glance at Gandy's incoming correspondence shows the intense advocacy for competing sites that might have derailed a more open process (as had happened in Portland).$^{52}$ Indeed, the initial Stadium Commission choice near Seattle Center was defeated by referendum in 1970, bringing reactivation of the commission, another detour around open politics, and a new site on the southern edge of the central business district. The resulting Kingdome gets few points for design excellence, but its availability for American League and National Football League teams confirmed Seattle's public standing as a "major league" city.

Underlining the different success in project planning and implementation was a contrasting willingness to pay for basic infrastructure. After meeting immediate postwar needs, voters in both cities were reluctant to spend money on anything but bare maintenance of public facilities. From 1952 through 1962, Portlanders said yes to eight tax base, tax levy, and bond measures proposed by the city, county, and school district and no to twenty. Seattle's voters accepted only three bond issues and rejected eight between 1952 and 1958. ${ }^{53}$ In the latter year, however, Seattle and King County residents took the bold step of creating the Municipality of

${ }^{50}$ John Haviland to Terry Schrunk, 27 April 1966; Ford Montgomery to Terry Schrunk, 26 April 1966; and Building Owners and Managers Association to Terry Schrunk, 2 June 1966; all in Box 4, Schrunk Papers. $10-16$.

${ }^{51}$ Sam Angeloff, "Are We Ready for the Big Leagues," Seattle Magazine, January 1964,

${ }^{52}$ For examples, see Bellevue Chamber of Commerce to James R. Ellis et al., 18 June 1968; and Brewster Denny to Joseph Gandy, 20 June 1968; both in Box 18, Gandy Papers.

${ }^{53}$ Portland voting record compiled from newspaper reports on elections; Seattle information from Banfield, Big City Politics, 144. 
Metropolitan Seattle to build the sewers and treatment plants necessary to preserve the attractions of Lake Washington. Although Seattle and King County voters turned down a multipurpose regional agency in March, they agreed in September to spend $\$ 125$ million on the single problem of water quality. ${ }^{54}$ Ten years later, business and political leadership coordinated Forward Thrust, an ad hoc process to develop a prioritized list of metro area capital needs. Forward Thrust was developed outside the structures of local government explicitly to force the support of local rival politicians. As attorney James Ellis commented during the Forward Thrust campaign, "some of us have just gotten sick and tired of trying to change the structure of local government. I tried myself for fifteen years, and I'm damned if I'm going to wait another fifteen before anything actually gets done." Again, Seattle and King County responded by approving $\$ 324$ million for highways, sewers, neighborhood improvements, fire protection, parks, and recreation. ${ }^{55}$

Portland was not so much cheap as it was slow in pursuing new port investment. Through the 1950s, Portland outpaced Seattle in general cargo movements and the bulk shipments of farm and forest products that traditionally constituted most of the trade over northwest docks. ${ }^{56}$ Portlanders supported new maritime facilities by voting $\$ 6.5$ million for the city's Commission of Public Docks in 1954 and $\$ 9.5$ million in 1960. However, the 1960 figure covered less than half of the needs list prepared by consultants ${ }^{57}$ Lacking the stable funding of a dedicated tax base and with no comprehensive plan in place, the Docks Commission waited three cautious years before it began to spend the money. Since the established operators in the Columbia River trade who dominated the Docks Commission agreed with outside consultants that the new technology of containerization was inappropriate for traditional regional bulk commodities, the funds finally went to improve familiar general cargo docks. ${ }^{58}$

${ }^{54}$ Roscoe C. Martin, Metropolis in Transition: Local Government Adaptation to Changing Urban Needs (Washington, 1963), 75-88; Mylon Winn, A Model of Organizational Development: A Case Study of the Municipality of Metropolitan Seattle (Ph.D. diss., University of Washington, 1982); and Municipality of Metropolitan Seattle, Twenty-Year Report, 1959-79 (Seattle, 1979).

${ }^{55}$ Ellis quoted in Patrick Douglas, "Politics: Forward Thrust," Seattle Magazine, January 1968, 29-32. Also see Forward Thrust, Inc., Developing a Capital Improvement Plan for a County, 4 vols. (Seattle, 1967).

${ }^{56}$ Stanley H. Brewer, The Competitive Position of Seattle and Puget Sound Ports in World Trade, University of Washington College of Business Administration, Management Series No. 7 (Seattle, 1963); and Padraic Burke, A History of the Port of Seattle (Seattle, 1976), 106, 110-11.

57 Oregonian (Portland), 20 June 1960; "Report on Dock Development Bonds," Portland City Club Bulletin 41 (28 October 1960).

58 Author's interview with Raymond Kell, Docks Commissioner and Port Commissioner, 11 June 1990, transcript in possession of author (hereafter Kell interview); Minutes of meeting of Metropolitan Planning Commission with Port of Portland and Commission of Public Docks, 20 August 1965, Box 2, David Eccles Papers, Oregon Historical Society, Portland, Oregon. 
The careful preservation of split decision-making further hampered effective port development. The city-appointed Docks Commission and the state-appointed Port of Portland divided responsibilities until they merged in 1970. The former maintained public marine terminals and built new ones, when it could pull together the money. Originally created to dredge the Willamette River channel, the latter agency added industrial development and operation of the regional airport. The Docks Commission saw itself as a scrappy agency that spoke for the ship captains and barge owners who knew the rivers. The Port of Portland represented the more Olympian views of bankers, clubmen, and inheritors of old wealth whose eyes were alert to real estate deals. Given the poor record of cooperation, the divided control of port development institutionalized caution through multiple veto points. ${ }^{59}$

Simultaneously, Seattle turned to facilities for containerized cargo out of a sense of necessity. A series of consultant studies and a KING-TV documentary on "Lost Cargo" articulated a growing crisis of confidence in Port of Seattle management in 1959, setting off several years of bureaucratic infighting and contests for the elected seats on the Port Commission. Firmly in place by 1963 , a new growth-oriented majority spent more than $\$ 100$ million to modernize and upgrade marine terminals and industrial land as a way to bypass Portland's historic advantage, and to compete directly with Oakland. The Port Commission gambled on the development of long range business in which containerized cargoes would move through Seattle in transit between Asia and the ports on the Atlantic. A reactivated Mayor's Maritime Advisory Committee after 1963 promoted port-based economic development and lobbied state and federal officials. The rhetoric of the revitalized port reflected its new energy, "catapulting" to "record-breaking performance" by the mid-1960s and "barreling full bore" in its "relentless escalation" toward full success. ${ }^{60}$

The results of the Portland and Seattle approaches were apparent in import-export data. The relative value of both import and export trade shifted to the advantage of Seattle between 1967 and 1977 (see Table 5). Portland retained its historic western role as an exporter of high bulk, low value commodities such as minerals, wood products, and farm products

59 "Report on Port Management, Operation and Development in the Metropolitan Portland and Columbia River Area," Portland City Club Bulletin 45 (26 April 1965); and Kell interview.

${ }^{60}$ Burke, Port of Seattle, 110-26; "The Maritime Industry's Magic Box," Seattle Magazine, May 1969, 52-55; Gordon Clinton to W. R. Norwood, 10 January 1963, in "Mayor's Maritime Advisory Committee" file, Box 27, Accession Group 239-2, Seattle Mayor's Papers, University of Washington Manuscripts Department, University of Washington, Seattle, Washington (hereafter Mayor's Papers); Reporter (Port of Seattle), 1 February 1967, in "Port Committee" file, Box 52, Mayor's Papers. 
while gaining selected high tonnage imports such as automobiles. Seattle developed as a comprehensive international port that shipped and received extensively-processed high-value goods. A key step came in 1970, when the development of new container terminals convinced a consortium of six Japanese shipping lines to make Seattle their first port of call on the West Coast. In 1967, Seattle exports carried an average value of $\$ .05$ per pound compared with $\$ .04$ for Portland. The comparable figures for 1986 were $\$ .36$ for Seattle and $\$ .08$ for Portland. ${ }^{61}$

Seattle also emerged as the Northwest's air-travel hub. Into the 1950s, the two cities had equal rail access to the East, while Portland enjoyed greater proximity to California. Both cities produced equal numbers of air passengers per thousand residents. ${ }^{62}$ When American carriers adopted passenger jets during the 1960s, however, Seattle gained a majority of direct long-distance flights. Airport expansion, starting in 1969, and aggressive competition for new route designations allowed Seattle to double Portland's air passenger miles and passengers per day by the early 1980s. Present-day Seattle can virtually match Portland's time-distance to California and offers superior access outside the West. ${ }^{63}$

One reason for Seattle's greater willingness to pursue extra-regional opportunities lies in the timing of generational transition. The expansion of Boeing with Korean War orders, Cold War contracts, and the 707 passenger jet required the recruitment of thousands of engineers and managers from beyond the Northwest. ${ }^{64}$ Expansion of the University of Washington multiplied this "Boeing effect." After divisive internal battles over political loyalty oaths during the early 1950 s, the university hired a new president with a new agenda in 1958. Enrollment had edged up from 12,271 in 1940 to 13,675 in 1956 and then exploded to 29,977 by 1968 . President Charles Odegaard encouraged faculty to tap the rapidly grow-

${ }^{61}$ Averages calculated from total tonnages and total value of shipments reported in the monthly volumes of U. S. Department of Commerce, U. S. Waterborne Exports and General Imports (Washington, DC).

621951 figures in Edward J. Taaffe, "Air Transport and United States Urban Distribution,” Geographical Review 46 (April 1956): 219-38.

${ }^{63}$ The Official Airline Guide indicates that Seattle in the 1970s and 1980s offered roughly 50 percent more direct and through flights to the east coast than did Portland. Passenger volumes are from John Tepper Marlin and James S. Avery, The Book of American City Rankings (New York, 1983). Lobbying efforts are discussed in Seattle Business, 5 April 1966. Expansion of Seattle-Tacoma International Airport is treated in Burke, Port of Seattle, 124. Major planned expansion of Portland International Airport in the early 1970s was stopped by analysis of its negative environmental impacts.

${ }^{64}$ In both 1960 and 1970, metropolitan Seattle had three and a half times as many employed engineers and technical workers as metropolitan Portland. Eighteenth Census of the United States, Vol. 1: Characteristics of the Population, Pt. 39, Table 74, and Pt. 49, Table 74 (Washington, DC); Nineteenth Census of the United States, Vol. 1: Characteristics of the Population, Pt. 39, Table 86, and Pt. 49, Table 86 (Washington, DC). 
ing pool of federal research funds in medicine and the sciences. ${ }^{65} \mathrm{~A}$ growing university helped to attract a Battelle Institute think tank in 1965. By 1977, Seattle occupied eighth place among all metropolitan areas in receipt of federal research and development dollars to universities and sixth place for total federal research and development funds. The university itself had changed from a regional educator to a national information producer. ${ }^{66}$

As utility executive Thomas Bolger pointed out during the Forward Thrust campaign, the growth of Boeing, the University of Washington, and business and university related activities made Seattle "a net importer of people and talent." ${ }^{67}$ Politically active citizens now included college educated professionals and managers with experience and connections outside Seattle. In contrast, statewide institutional and community jealousies retarded the evolution of Portland State College into a major university. Portland lacked the economic multiplier from a large body of out-of-town students and from faculty research grants. It also lacked Seattle's dense network of connections within national educational and research systems. Something comparable to the impact of Boeing did not appear in Portland's stable industrial structure until the rapid growth of the electronics industry in the $1970 \mathrm{~s} .{ }^{68}$ The results can be read from census data on the proportion of adults twenty-five years or older with four or more years of college. In 1950, Portland's 7.5 percent lagged behind Seattle's 9.7 percent. The gap had widened by 1970 , with 12.8 percent of Portlanders and 15.9 percent of Seattleites holding college degrees. ${ }^{69}$

Patterns of internal migration also show the importance of newcomers for setting Seattle's civic tone. Census reports include data on migration among state economic areas from 1955 to 1960 and from 1965 to

${ }^{65}$ Enrollment data from American Council on Education, American Colleges and Universities, 4th through 13th editions, covering 1940 to 1986 at irregular intervals. Also Charles M. Gates, The First Century at the University of Washington, 1861-1961 (Seattle, 1961), 216-19; Jane Sanders, Into the Second Century: The University of Washington, 1961-1986 (Seattle, 1987); and Sale, Seattle, 208-10.

${ }^{66}$ Edward Malecki, "Federal R \& D Spending in the United States of America: Some Impacts on Metropolitan Economies," Regional Studies 16 (1982), 19-35. Argus (Seattle), 9 July 1965, reported that federal grants at the University of Washington nearly matched state general fund support by 1964 .

${ }^{67}$ Thomas Bolger, "The Forward Thrust Story," speech to Vancouver Rotary Club, 4 June 1968, in Developing a Capital Improvement Plan, Vol. 4: Selected Speeches on Forward Thrust, 82 by Forward Thrust, Inc.

${ }^{68}$ Gordon B. Dodds and Craig E. Wollner with the assistance of Marshall M. Lee, The Silicon Forest: High Tech in the Portland Area, 1945 to 1986 (Portland, 1990).

69 Seventeenth Census of the United States, Vol. 2: Characteristics of the Population, Pt. 37, Table 34, and Pt. 47, Table 34 (Washington, DC); Eighteenth Census of the United States, Vol. 1: Characteristics of the Population, Pt. 39, Table 73, and Pt. 49, Table 73 (Washington, DC); and Nineteenth Census of the United States, Vol. I: Characteristics of the Population, Pt. 39, Table 83, and Pt. 49, Table 83 (Washington, DC). 
1970 (see Table 6). During both periods, Seattle drew a higher proportion of its residents from beyond the Pacific states and greater Northwest (Nevada, Idaho, Montana, Utah, Wyoming, and the Dakotas). In 1960, roughly 54,000 King County residents had arrived from the more distant parts of the United States since 1955, but only 25,000 new residents of metropolitan Portland. For 1970, the parallel figures were 68,000 and 30,000 . The contrasting totals reflect the greater need and ability of Seattle enterprises to tap national labor markets and the city's greater attraction for footloose migrants. In turn, the newcomers found both a guidebook and a voice in Seattle Magazine (1964-1971), whose articles and columns exposed local issues, profiled politicians and businessmen, reviewed neighborhoods, and introduced new Seattleites to their city. ${ }^{70} \mathrm{~A}$ growing and changing community supported a spirit of civic optimism in Seattle in the 1960s. The weekly Argus mounted a vigorous campaign to energize city politics. The venerable Municipal League changed from the conservative voice of what the Argus called the "mature oligarchy" to a more active advocate of government reform. ${ }^{71}$ Metro's visible success with Lake Washington and the underpinning of prosperity during the 1960s created a window of opportunity for civic action. Community activist James Ellis later recalled the origins of Forward Thrust:

The business leadership had been so successful with the World's Fair, the civic leadership had been successful with Metro in cleaning up Lake Washington, and both of those big initiatives, which were citizen-led, had had tremendously effective public official participation.... The public generally had the view then that there was almost nothing that this community couldn't tackle and win. It was a very upbeat time in this area, and I've lived here all my life, and I don't know of any other times when I've seen so much optimism generally shared by the public. ${ }^{72}$

If generational change and community confidence help to explain the greater responsiveness of Seattle voters to civic initiatives, historical continuities seem more relevant to different attitudes in club rooms and board rooms. Portland in the 1960s confirms Daniel Elazar's characterization of Oregon as a state of moralistic politics. Government was seen as an enforcer of rules and barrier against impetuous action. Reasoning by analogy from the realm of individual ethics, conservative Portland tended to regard public debt as a flaw of civic character. At best, Portland's moralistic politics have prompted open decision-making and public processes

${ }^{70}$ Sale, Seattle, 212-15.

${ }^{71}$ Argus (Seattle), 19 September 1958, 12 May 1961, 10 April 1964, and 7 August 1964.

72 Transcript of interview of James Ellis by Lorraine McConaghy, 13 October 1988, Seattle Parks Department, 1-2, transcript in possession of author. Also see Mechlin D. Moore, speech to Central Seattle Association, 10 May 1966, in "Central Association of Seattle" file, Box 38, Mayor's Papers. 
that have ensured careful planning. ${ }^{73}$ At its least effective, the same emphasis on process has meant a distrust of active government and a willingness to accept multiple vetoes by popular referendum, legislative inaction, and conflicting economic interests. ${ }^{74}$

Seattle's contrasting tradition of individualistic politics treated active government as an instrument for creating economic value. The Seattle system was open to self-interest and corruption, as with labor-management collusion in the $1940 \mathrm{~s}^{75}$ It was also amenable to the definition and pursuit of a positive common good. Seattleites in the 1960s accepted ad hoc decision-making in the interest of accomplishing their development agenda. The city's project orientation allowed its commercial-civic leadership to detour around the potential delays and vetoes of the formal political process. In a sense, Seattle leaders accepted a set of operating rules that looked back to the Alaska myth as legitimation of active community entrepreneurship. ${ }^{76}$

By the time Portland felt the equivalent of Seattle's civic energy in the 1970s, Seattle's evolution into a network city had a ten- or twelve-year lead. ${ }^{77}$ Historical analysis confirms and provides a context for recent studies that emphasize Seattle's extra-regional ties in specific industrial sectors such as manufacturing and services. ${ }^{78}$ The results can be summed up as the contrast between a "Northwest city" and a "Pacific city." As it did a century ago, Portland still functions as a gateway for regional commerce and as a service center for portions of three states. Seattle increasingly participates in the long-range networks of finance, investment, tourism, and trade that link the North American and East Asian core regions of the world economy. It outranks Portland not only in the volume and

${ }^{73}$ Daniel J. Elazar, American Federalism: A View From the States (New York, 1972); Carl Abbott, "Urban Design in Portland, Oregon, as Policy and Process, 1960-1989," Planning Perspectives 6 (Winter 1991): 1-18 examines the positive effects of the process orientation.

${ }^{74}$ E. Kimbark MacColl, "Portland: First Class on a Steerage Ticket," The New Pacific 1 (Summer 1990): 41-49 explores Portland's ingrained conservatism. Portland attorney and political insider Raymond Kell contrasted the strong anti-tax sentiment in Portland with Seattle's willingness to "mortgage everything they had" to pursue economic development, Kell interview.

${ }^{75}$ Green, American Cities, 189-92.

${ }^{76}$ The same contrast between process and project orientations continued to characterize downtown development planning in the 1970s and 1980s. See Mark R. Bello, "Urban Regimes and Downtown Planning in Portland, Oregon, and Seattle, Washington, 1974-1990" (Ph.D. diss. in progress, Portland State University). Seattleites reminded themselves of the city's go-getter heritage by purchasing thousands of copies of William C. Speidel, Sons of the Profits, or There's No Business Like Grow Business: The Seattle Story, 1851-1901 (Seattle, 1967).

${ }^{77}$ Abbott, Portland, 167-277.

$\rightarrow$ William B. Beyers, "On Geographical Properties of Growth Center Linkage Systems," Economic Geography 50 (July 1974): 203-18; William Beyers, "Export Services in Postindustrial Society," Papers of the Regional Science Association 57 (1985): 33-48; and Pred, City-Systems in Advanced Economies. 
value of overseas trade, but also in the number of direct overseas flights, number of foreign bank offices, amount of foreign investment, number of professional consular officers, and proportion of foreign born residents. $^{79}$

Examination of urban growth in the Pacific Northwest confirms that urban rivalry remains a fruitful topic for historians interested in twentiethcentury cities. A number of historians, most prominently Roger Lotchin, have explored the definition of network-oriented growth strategies as city boosters have looked to federal spending or international trade. This essay offers a framework for measuring the relative importance of such transregional connections. The dual system model may be applicable to the changing fortunes of cities in other parts of North America. Pairs of cities that may be comparable to Portland and Seattle include Birmingham and Atlanta, Cincinnati and Columbus, Cleveland and Pittsburgh, or San Antonio and Dallas. Across the northern border, the rise of Toronto relative to Montreal is similarly attributed to the shifting location of network activities. ${ }^{80}$

Attention to the role of network factors in urban rivalries suggests a way to structure the historical analysis of local responses to the changing scale of activity and the changing range of opportunities in the national and international economies. ${ }^{81}$ Many specialists now recognize "world cities" as a distinct type of metropolis that absorbs a disproportionate share of economic and political control functions. The world city or global city is a specialized producer of financial and business services and a wholesaler of the nonregionalized resources of public information, private intelligence, and capital..$^{82}$ Most writers, however, are content to inventory the distribution and character of world cities while ignoring the

79 Banker, March 1988, 37-61; "Japanese Investors Prefer California," Chronicle (San Francisco), 28 December 1989; and K. Leventhal and Co., 1988 Japanese Investment in U. S. Real Estate (Los Angeles, 1989).

${ }^{80}$ Diana Hooper, J. W. Simmons, and L. S. Bourne, The Changing Economic Basis of Canadian Urban Growth, 1971-1981, Center for Urban and Community Studies, Toronto, Research Paper 139, 1983.

${ }^{81}$ In ways different from this essay, two recent books have taken on the question of citylevel responses to the changing scale of the national economy. Don $\mathrm{H}$. Doyle, in New Men, New Cities, New South: Atlanta, Nashville, Charleston, Mobile, 1860- 1910 (Chapel Hill, NC, 1990), examines the successes and failures of the urban business class of the postbellum South in implementing the "New South" goals of integration into the national industrial economy. The focus of John T. Cumbler, A Social History of Economic Decline: Business, Politics, and Work in Trenton (New Brunswick, NJ, 1989) is the character of local responses to the shift from locally based "civic capitalism" to larger scale "national capitalism" or "bureaucratic corporatism." His model of the impacts of scale change on local decisions and decision-makers draws on Robert Merton's distinction between local and cosmopolitan leadership in Robert K. Merton, Social Theory and Social Structure (Glencoe, IL, 1957).

${ }_{82}$ Peter Hall, The World Cities (New York, 1966); R. B. Cohen, "The New International Division of Labor, Multinational Corporations, and Urban Hierarchy," in Urbanization and Urban Planning in Capitalist Society, ed. Michael Dear and Allan J. Scott (New York, 1981); 
question of origins. They are much better at detailing what such cities do and what they are like than at explaining why Hong Kong is on everybody's list but Panama City is not. For one nation, at least, attention to the changing balance of regional, national network, and international network functions over several decades may be an appropriate avenue for exploring the way in which the United States has structured its developing participation in the world urban system.

John Friedmann and Goetz Wolff, "World City Formation: An agenda for research and action," International Journal of Urban and Regional Research 6 (September 1982): 309-44; John Friedmann, "The World City Hypothesis," Growth and Change 17 (1986): 69-83; and Mattei Dogan and John D. Kasarda, eds., The Metropolis Era: A World of Giant Cities, Vol. 1(Newbury Park, CA, 1988). 
TABLE 1

Seattle and Portland Population

Seattle

1880

1890

1900

1910

1920

1930

1940

1950

1960

1970

$1980 \mathrm{a}$

$1990 \mathrm{a}$

$1980 \mathrm{~b}$

$1990 \mathrm{~b}$
3,553

42,837

80,871

237,174

357,950

420,663

452,639

844,572

$1,107,213$

$1,421,869$

$1,607,469$

$1,972,961$

$2,093,000$

$2,559,164$
Portland

17,577

46,385

90,426

207,214

299,882

378,728

406,406

704,829

821,897

$1,009,129$

$1,242,594$

$1,412,344$

$1,298,000$

$1,477,895$
Seattle:Portand

.92

.89

1.14

1.19

1.11

1.11

1.20

1.35

1.41

1.29

1.40

1.61

1.73

1880-1910: $\quad$ Cities

1920-1940: $\quad$ Metropolitan districts

1950-1990a: Populations within 1960 SMSA boundaries

1980b-1990b: Standard Consolidated Metropolitan Areas

TABLE 2

Relative Population and Personal Income:

Ratios of Seattle and Portland Hinterlands

Population

(1)

1900

1910

1920

1930

1940

1950

1960

1970

1980
1.44

1.73

1.71

1.57

1.48

1.43

1.50

1.50

1.41
(2)

1.58

1.94

1.97

1.80

1.63

1.58

1.60

1.56

1.49
Income

(3) (4)

1.62

1.82

1.56

1.76

1.49

1.66

1.58

1.64

1.62

1.67

1.54

(1): Population in OR and WA weighted 1, population in AK, ID and MT weighted 0.5

(2): Same as (1), less Seattle and Portland city populations (1900-10), metropolitan district populations (1920-40), or populations within 1960 SMSA boundaries (1950-80)

(3): Personal income in OR and WA weighted 1, personal income in AK, ID, and MT weighted 0.5 [WA per capita income used for AK for 1930 and 1940]

(4): Same as (3), less Seattle and Portland city populations (1900-10), metropolitan district populations $(1920-40)$, or populations within 1960 SMSA boundaries $(1950-80)$

For hinterland definitions, see Note 26. 
TABLE 3

EMPLOYMENT IN REGIONALLY-BASED MANUfACTURING

Regionally-Based Manufacturing as Percent of all Employment

Seattle Portland $\quad$ Peattle:

$\begin{array}{llll}1909 & 4.7 & 5.7 & .82\end{array}$

$\begin{array}{llll}1919 & 4.8 & 6.2 & .69\end{array}$

\begin{tabular}{|c|c|c|c|}
\hline 1930 & 3.1 & 4.7 & .66 \\
\hline$-----\frac{-}{1940}$ & $\overline{9} . \overline{0}$ & $\overline{13.0}$ & $-\overline{69}-$ \\
\hline 1950 & 6.8 & 12.4 & .55 \\
\hline 1960 & 6.9 & 11.5 & .60 \\
\hline 1970 & 4.8 & 7.9 & .61 \\
\hline 1980 & 3.6 & 6.2 & .58 \\
\hline
\end{tabular}

See Note 27 for definition of category and sources. The figures for 1909-19, for 1930 , and for 1940-80 were derived from data compiled according to different principles.

\section{TABLE 4}

Seattle and Portland as Primate Cities

\section{Ginsburg Index}

Seattle Portland

$\begin{array}{lll}1900 & .44 & .81 \\ 1910 & .51 & .83 \\ 1920 & .55 & .85 \\ 1930 & .57 & .85 \\ 1940 & .58 & .84 \\ 1950 & .58 & .86 \\ 1960 & .63 & .82 \\ 1970 & .65 & .76 \\ 1980 & .75 & .73\end{array}$

Ginsburg Index = population of largest city in region divided by total population of four largest cities in region

Seattle and Portland regions defined as in Table 2 (see Note 26)

Metropolitan district populations used when designated for 1920-40; metropolitan area populations for 1950-70; consolidated metropolitan area populations for 1980 . 


\section{TABLE 5}

Seattle-Everett and Portland-Vancouver Waterborne ForEIGN TRADE (\$1 MILLIONS)

\begin{tabular}{ccccc}
\multicolumn{2}{c}{ Exports } & \multicolumn{2}{c}{ Imports } \\
Seattle & Portland & S:P & Seattle Portland & S:P
\end{tabular}

$\begin{array}{rrrrrrr}1967 & \$ 203 & \$ 385 & .53 & \$ 205 & \$ 173 & 1.18 \\ 1972 & 348 & 388 & .90 & 1655 & 350 & 4.73 \\ 1977 & 883 & 765 & 1.15 & 3966 & 1159 & 3.42 \\ 1982 & 2759 & 2048 & 1.35 & 10,251 & 2167 & 4.86 \\ 1986 & 4194 & 1873 & 2.24 & 19,084 & 3940 & 4.84\end{array}$

Source: U.S. Department of Commerce, U. S. Waterborne Exports and General Imports

\section{TABLE 6}

Origins of Domestic ImMigRants to SEATtLe and PortLand, 1955-60 AND 1965-70

$\begin{array}{lll}\text { Oregon and } & \text { Other Pacific or } & \text { Other } \\ \text { Washington } & \text { Northwest States } & \text { U.S. }\end{array}$

$1955-60$

$\begin{array}{lccc}\begin{array}{l}\text { Seattle SEA } \\ (163,916 \text { total })\end{array} & 46 \% & 21 \% & 33 \% \\ \begin{array}{l}\text { Portland SEA } \\ (105,237 \text { total })\end{array} & 50 \% & 26 \% & 24 \%\end{array}$

1965-70

$\begin{array}{lccc}\begin{array}{l}\text { Seattle SEA } \\ (218,935 \text { total })\end{array} & 36 \% & 33 \% & 31 \% \\ \begin{array}{l}\text { Portland SEA } \\ (137,044 \text { total })\end{array} & 44 \% & 34 \% & 22 \%\end{array}$

Seattle State Economic Area: King County

Portland State Economic Area: Multnomah, Washington, and Clackamas counties

Sources: U.S. Census of Population, 1960, Subject Report PC (2E):

Migration Between State Economic Areas

U.S. Census of Population, 1970, Subject Report PC(2)-2E:

Migration Between State Economic Areas 